\title{
Impacts of combined temperature and salinity stress on the endemic Arctic brown seaweed Laminaria solidungula J. Agardh
}

\author{
Nora Diehl $^{1}$ (D) . Ulf Karsten ${ }^{2}$ (D) Kai Bischof $^{1}$ (D)
}

Received: 15 October 2019 / Revised: 3 April 2020 / Accepted: 6 April 2020 / Published online: 16 April 2020

(c) The Author(s) 2020

\begin{abstract}
Macroalgae such as kelp are important ecosystem engineers in the Polar Regions and potentially affected by freshening and ocean warming. The endemic Arctic kelp Laminaria solidungula might be particularly imperiled and become locally extinct from Arctic fjord systems in the future, since temperature increase is most pronounced in the Polar Regions. Additionally, increased temperatures cause glacier and sea ice melting and enhancing terrestrial run-off from snowfields, which eventually can result in hyposaline conditions in fjord systems. We conducted a multiple-stressor experiment at four temperatures $\left(0,5,10,15^{\circ} \mathrm{C}\right)$ and two salinities $\left(S_{\mathrm{A}} 25,35\right)$ to investigate the combined effects of increasing temperature and decreasing salinities on the physiological and biochemical status of young L. solidungula sporophytes. Both drivers had significant and interacting impacts, either in an additive or antagonistic way, dependent on the respective response variable. The maximum quantum yield of photosystem II $\left(F_{\mathrm{v}} / F_{\mathrm{m}}\right)$ significantly declined with temperature increase and low salinity. Even though the absolute pigment content was not affected, the deepoxydation state of the xanthophyll cycle increased with intensified stress. Higher temperatures affected the C:N ratio significantly, mainly due to reduced nitrogen uptake, while $S_{\mathrm{A}} 25$ supported the nitrogen uptake, resulting in an attenuation of the effect. The concentration of mannitol decreased at $S_{\mathrm{A}} 25$. At control $S_{\mathrm{A}}$ 35 mannitol level remained steady between 0 and $10{ }^{\circ} \mathrm{C}$ but significantly decreased at $15{ }^{\circ} \mathrm{C}$. Conclusively, our results show that $L$. solidungula is very susceptible to both drivers of climate change, especially when they are combined. Implications to species ecology are discussed.
\end{abstract}

Keywords Kelp $\cdot$ Multiple-stressor $\cdot$ Mannitol $\cdot F_{\mathrm{v}} / F_{\mathrm{m}} \cdot \mathrm{C}: \mathrm{N} \cdot \mathrm{DPS}$

\section{Introduction}

Temperature increase is one of the major drivers of climate change. The strongest regional warming over the last 30 years was detected in the Polar Regions (Maturilli et al. 2013; Meredith et al. 2019). Elevated air and sea water temperatures cause glacier and sea ice melting and increased terrestrial run-off from snowfields (Sundfjord et al. 2017;

Electronic supplementary material The online version of this article (https://doi.org/10.1007/s00300-020-02668-5) contains supplementary material, which is available to authorized users.

Nora Diehl

ndiehl@uni-bremen.de

1 Marine Botany, Faculty of Biology and Chemistry, University of Bremen, 28359 Bremen, Germany

2 Applied Ecology and Phycology, Institute of Biological Sciences, University of Rostock, 18059 Rostock, Germany
Filbee-Dexter et al. 2019). Consequently, increased temperatures may result in hyposaline conditions in Arctic fjords, due to limited seawater exchange and stratification (Svendsen et al. 2002). Between 1936 and 1999 total fresh water inflow into the Arctic Ocean increased by about 7\% (Bluhm and Gradinger 2008). Under regular conditions, seawater salinity in Arctic fjords averages $S_{\mathrm{A}} 34.5 \mathrm{in}$ spring, and can drop below $S_{\mathrm{A}} 23$ at the sea surface (Karsten et al. 2003; Zacher et al. 2009). However, salinity in deeper water layers down to $20 \mathrm{~m}$ may also be affected after vertical mixing by wave and wind action (Hanelt et al. 2001). Average seawater temperatures in Kongsfjorden, Svalbard are $4{ }^{\circ} \mathrm{C}$ during summer, but can reach a maximum of $5-7^{\circ} \mathrm{C}$ (Hanelt et al. 2001; Svendsen et al. 2002; Bartsch et al. 2016). In 2019, these maxima were exceeded reaching almost $8{ }^{\circ} \mathrm{C}$, which demonstrates the regional fast increases of seawater temperature (unpublished; Dashboard AWI 2019). In other Arctic regions, the sea surface temperature has already increased up to $8-10{ }^{\circ} \mathrm{C}$ (Wiencke et al. 2007). Long-term trends for 
the Arctic region predict a further increase in warming and reduction of sea ice cover (Müller et al. 2009; Walczowski et al. 2012; Oliver et al. 2018), and increasing temperatures, especially heat wave events, are likely to impact many marine species (Smale et al. 2019).

Arctic macroalgae are specifically affected by freshening and ocean warming (Hanelt et al. 2001). More than 140 seaweed species in the Arctic region have been described so far, most of them growing in the sublittoral (Hop et al. 2012). Kelps, large brown seaweeds of the order Laminariales, are important ecosystem engineers in Arctic fjords. The only endemic kelp species from the Arctic is Laminaria solidungula J. Agardh, which can be found down to depths of $18 \mathrm{~m}$ (Roleda 2016). It grows at temperatures up to $16{ }^{\circ} \mathrm{C}$ with an optimum at $5-10{ }^{\circ} \mathrm{C}$ (tom Dieck (Bartsch) 1992). Despite the general ability of seaweeds to acclimate to variation in temperature and other environmental drivers (e.g., Davison et al. 1991; Bischof et al. 2002; Graiff et al. 2015b; Diehl et al. 2019), there is growing concern that $L$. solidungula might become locally extinct from Arctic fjord systems in the future (Müller et al. 2009). Temperature stress can result in structural weakening of kelp tissue (Simonson et al. 2015b) and has an influence on carbon and nitrogen content, due to structure and nitrogen storage (Atkinson and Smith 1983; Peters et al. 2005). It also affects photosynthetic quantum yield $\left(F_{\mathrm{v}} / F_{\mathrm{m}}\right)$ and pigment concentrations (Andersen et al. 2013; Fernandes et al. 2016). Various, potentially interacting, drivers may additionally influence kelp fitness and competitive success. In order to cope with variation in environmental drivers, such as salinity or irradiation, seaweeds developed different acclimation mechanisms to maintain cellular functions (e.g., Karsten and West 2000; Eggert et al. 2007; Rautenberger et al. 2015; Ji et al. 2016). Among others, brown algae synthesize the polyol mannitol to compensate osmotic stress (Iwamoto and Shiraiwa 2005). Mannitol acts as a compatible solute, by conserving intracellular homeostasis and potentially functioning as antioxidant (Kirst 1989; Iwamoto and Shiraiwa 2005; Eggert et al. 2007). Furthermore, it is known that salinity changes substantially affect nitrogen metabolism in seaweed (Gordillo et al. 2002; Mandal et al. 2015).

Consequently, kelp forests have already been directly and indirectly impaired by large-scale environmental change (Müller et al. 2009; Bartsch et al. 2016). Until today most studies on environmental impacts on seaweeds were designed as uni-factorial experiments (e.g., Bischof 2002; Karsten 2007; Wiencke et al. 2007; Olischläger et al. 2012; Simonson et al. 2015a) or studied interactions between irradiation or acidification and temperature (e.g., Fredersdorf et al. 2009; Heinrich et al. 2015; Gordillo et al. 2016; Springer et al. 2017).

While the effects of irradiance and temperature on kelps have been studied in detail, little is known on salinity tolerance of polar seaweeds (e.g., Karsten et al. 1991a, b; Jacob et al. 1991; 1992; Karsten 2007; Li et al. 2019), and even less on salinity temperature interactions (Russell 1987; Thomas et al. 1988; Fredersdorf et al. 2009; Mandal et al. 2015), especially with regard to the endemic kelp $L$. solidungula.

The present study reveals physiological and biochemical responses to increasing temperature and changing salinities for the hitherto understudied Arctic endemic kelp species Laminaria solidungula. Results obtained shed light on the adaptive responses of the species to predict kelp performance in a continuously changing Arctic environment.

\section{Material and methods}

\section{Laminaria solidungula cultivation}

A gametophyte strain of Laminaria solidungula (as stock culture obtained from the Alfred Wegener Institute for Polar and Marine Research, Bremerhaven, Germany; AWI culture number 3130 - not separated into male and female gametophytes) from Spitsbergen was fragmented into multicellular gametophyte filaments and subjected to $0{ }^{\circ} \mathrm{C}$, short-day conditions (4:20-h-light:dark [LD]) for induction of fertility (tom Dieck 1989). After a month, fragments were transferred into long-day conditions (16:8-h-LD). The first sporophytes became visible after 2 months, and were transferred into larger aerated glassware during growth. The size of the glassware was adapted to the size of sporophytes. After 5 months, the sporophytes were transferred to $5{ }^{\circ} \mathrm{C} 16: 8$-h-LD conditions to promote further growth. The sporophytes were cultivated at a photon fluence rate of $30 \mu \mathrm{mol}$ photons $\mathrm{m}^{-2} \mathrm{~s}^{-1}$ (ProfiLux 3 with LED Mitras daylight 150, GHL Advanced Technology, Kaiserslautern, Germany). The sporophytes were initially cultivated with full Provasoli-enriched seawater (PES; sterile sea water from the North Sea) and after another 5 months onwards in $1 \frac{1}{2}$ PES (with Hepes buffer, respectively). The medium was changed every 1-2 weeks. One month later, the sporophytes were once again transferred into $0{ }^{\circ} \mathrm{C}$ to delay growth until the experiment was conducted 6 weeks later.

\section{Two-factorial stress experiment: temperature and salinity}

Young sporophytes of Laminaria solidungula were maintained in aerated 2-L Kautex bottles filled with 1/2 PES at an artificial photon fluence rate of $30 \mu \mathrm{mol} \mathrm{m}^{-2} \mathrm{~s}^{-1}$ and a 16:8-h-LD (ProfiLux 3 with LED Mitras daylight 150, GHL Advanced Technology, Kaiserslautern, Germany). The medium was changed twice a week. The samples were acclimated to four different temperatures $\left(0,5,10,15{ }^{\circ} \mathrm{C}\right)$ 
within 1 week. The salinity treatments $\left(S_{\mathrm{A}} 25\right.$ and 35$)$ were started after temperature acclimation. The hyposaline conditions were maintained by diluting the sterile sea water (North Sea) with freshwater (tab water). The treatment $0{ }^{\circ} \mathrm{C}$, $S_{\mathrm{A}} 35$ was used as control. Four sporophytes were cultivated as replicates $(n=4)$ per treatment. After being maintained at treatment conditions for 14 days, all samples were shock frozen in liquid $\mathrm{N}_{2}$, stored at $-80^{\circ} \mathrm{C}$, and freeze-dried before biochemical analyses.

\section{Response variables}

\section{Photo-ecophysiological markers}

The photosynthetic performance of the meristem was determined every fourth day by measuring the in vivo chlorophyll-fluorescence of photosystem II (PSII) using an Imaging-PAM (Walz GmbH Mess- und Regeltechnik, Effeltrich, Germany), after 5 min of dark acclimation. The PAM was set up to determine the amplitude of the fluorescence signal $\left(F_{\mathrm{t}}\right)$ between 0.15 and 0.2 as recommended in the manual (IMAGING-PAM M-Series Chlorophyll Fluorometer, Heinz Walz GmbH, Effeltrich, Germany). The maximum quantum yield of photosystem II $\left(F_{\mathrm{v}} / F_{\mathrm{m}}\right)$ represents a sensitive indicator of photosynthetic performance and, hence, of algal fitness, which might be affected by stress exposure (Kirst 1989; Nitschke et al. 2014; Ji et al. 2016).

Photosynthetic and accessory pigments $(n=4)$ were extracted and analyzed following exactly Koch et al. (2015). Therefore, $0.05-0.1 \mathrm{~g}$ freshly freeze-dried samples were extracted in $1 \mathrm{~mL}$ Acetone $\left(90 \%\right.$, v/v), incubated at $4{ }^{\circ} \mathrm{C}$ for $24 \mathrm{~h}$ in darkness and analyzed with a High-Performance Liquid Chromatography (HPLC). The concentrations of chlorophyll $a$ and $\mathrm{c} 2$ (Chl $a$, Chl c2), fucoxanthin (Fuc), $\beta$-carotene ( $\beta$-Car) as well as the pool-size of the xanthophyll cycle $(\mathrm{VAZ}=$ violaxanthin, antheraxanthin, zeaxanthin) were calculated as $\mu \mathrm{g} \mathrm{g}^{-1}$ dry weight (DW). The deepoxydation state (DPS) of the xanthophyll cycle was calculated after Colombo-Pallotta et al. (2006).

Additionally, the antioxidant phlorotannin was determined after Springer et al. (2017) using the Folin-Ciocalteu method described in Cruces et al. (2012). $20 \mathrm{mg}$ of freezedried sample $(n=4)$ was extracted in $1 \mathrm{~mL}$ Acetone $(70 \%$ $\mathrm{v} / \mathrm{v}$ ) and incubated for $24 \mathrm{~h}$ at $4{ }^{\circ} \mathrm{C}$ in darkness. For the analyses, the absorption at $\lambda 730 \mathrm{~nm}$ of three aliquots per replicate was determined in a microplate photometer. The total soluble phlorotannin concentration was expressed in $\mathrm{mg} \mathrm{g}^{-1} \mathrm{DW}$.

\section{Mannitol}

$1 \mathrm{~mL}$ aqueous Ethanol (70\%, v/v) was added to three aliquots of 15-20 mg of each lyophilized and homogenized sample and incubated in a water bath at $70{ }^{\circ} \mathrm{C}$ for $3-4 \mathrm{~h}(n=4)$. The vials were vortexed occasionally to keep the samples dispersed. Initially, samples were centrifuged (5 min; $13,000 \mathrm{rpm}$ ) and $800 \mu \mathrm{L}$ of the supernatant was transferred to a fresh vial and evaporated to dryness (Alpha 1-4 LSCplus and RVC 2-25 CDplus, Martin Christ Gefriertrocknungsanlagen $\mathrm{GmbH}$, Osterode am Harz, Germany). The pellets were re-dissolved by vortexing and ultrasonic treatments in $800 \mu \mathrm{L}$ HPLC grade water. The samples were then centrifuged for another $5 \mathrm{~min}(13,000 \mathrm{rpm})$. The obtained supernatant was analyzed using the method of Karsten et al. (1991a) in a HPLC Agilent Technologies system (1200 Series, Santa Clara, California, USA) with an Aminex Fast Carbohydrate Analysis Column HPAP $(100 \times 7.8$ $\mathrm{mm}, 9-\mu \mathrm{m}$, BioRad, Munich, Germany), protected by a guard cartridge (Phenomenex, Carbo-Pb- $+4 \times 3.00$ mm I.D., Aschaffenburg, Germany) with $100 \% \mathrm{dH}_{2} \mathrm{O}$ as a mobile phase. The flow rate was adjusted to $1 \mathrm{~mL} \mathrm{~min}^{-1}$ at $10-100$ bar and $70^{\circ} \mathrm{C}$. For the calibration $0.5,1.0,2.5$, 5.0 and $10.0 \mathrm{mM}$ D(-)-mannitol standards $\left(\mathrm{C}_{6} \mathrm{H}_{14} \mathrm{O}_{6}\right.$, Roth) were used. Absorption peaks were detected via RI-Detector $\left(35^{\circ} \mathrm{C}\right)$ and analyzed using the software 'ChemStation for LC 3D systems' (Agilent Technologies, Waldbronn, Germany). Mannitol contents were calculated in $\mu \mathrm{mol} \mathrm{g}^{-1}$ dry weight (DW).

\section{Carbon, nitrogen and C: $\mathrm{N}$ ratio}

Total carbon $(\mathrm{C})$ and total nitrogen $(\mathrm{N})$ concentrations as well as $\mathrm{C}: \mathrm{N}$ ratios were analyzed following Graiff et al. (2015a). Three aliquots of $2 \mathrm{mg}(n=4)$ of lyophilized and ground samples were weighed into tin cartridges $(6 \times 6 \times 12-\mathrm{mm})$ and combusted at $950{ }^{\circ} \mathrm{C}$. Acetanilide $\left(\mathrm{C}_{8} \mathrm{H}_{9} \mathrm{NO}\right)$ was used as standard (Verardo et al. 1990). The contents of $\mathrm{C}$ and $\mathrm{N}$ were quantified automatically in an elemental analyzer (Vario EL III, Elementar, Langenselbold, Germany). Total $\mathrm{C}$ and total $\mathrm{N}$ contents were expressed in $\mathrm{mg} \mathrm{g}^{-1}$ dry weight (DW).

\section{Statistical analysis}

All datasets were tested for normal distribution (Shapiro-Wilk test; $p>0.05$ ) and for homogeneity (Levene's test; $p>0.05)$. Data were transformed if needed. Afterwards, two-way ANOVAs were performed for each parameter $(p<0.05)$ and a post hoc Tukey's test applied to reveal significant differences $(p<0.05)$. The pigment datasets were analyzed using the generalized linear model (GLM) $(p<0.05)$. The statistical analyses were run using RStudio (Version 1.1.383, Boston, MA, USA) and Excel 2016 (Windows; Microsoft Corporation, Redmond, WA, USA). 


\section{Results}

\section{Photo-ecophysiology}

After 14 days, photosynthetic maximum quantum yield $\left(F_{\mathrm{v}} / F_{\mathrm{m}}\right)$ showed a significant decrease at $15{ }^{\circ} \mathrm{C}$ in both salinities and was significantly lower than the control treatment $\left(F_{3}=62.866, p<0.0001\right)$. In all other treatments, the maximum values of $0.684 \pm 0.012(n=4)$ were maintained, independent of temperature or salinity. After 7 days of temperature acclimation, $F_{\mathrm{v}} / F_{\mathrm{m}}$ differed between the four temperatures $(0.595 \pm 0.015-0.678 \pm 0.010$; control: $0.616 \pm 0.017 ; n=4)$ but did not significantly change with temperature and salinity stress during the first 11 days of the experiment (Fig. 1). The low salinity treatment at $15{ }^{\circ} \mathrm{C}$ impaired $F_{\mathrm{v}} / F_{\mathrm{m}}$ significantly stronger than the control salinity treatment $\left(S_{\mathrm{A}} 25: 0.396 \pm 0.128 ; S_{\mathrm{A}} 35\right.$ : $0.533 \pm 0.034 ; n=4 ; p=0.0001$ ) (Fig. 1).

Pigment concentrations (GLM: $p<0.05$, details: Supplementary Table 1) and phlorotannin concentrations (temperature: $F_{3}=11.115, p<0.0001$; salinity: $F_{1}=5.884$, $p=0.0232$; interaction: $F_{3}=3.078, p=0.0467$ ) exhibited few significant differences, which, however, could not be assigned to any of the stress treatments (Table 1). Nevertheless, the deepoxydation state of the xanthophyll cycle (DPS) was significantly affected by temperature $\left(F_{3}=12.087\right.$, $p<0.0001)$. At $15^{\circ} \mathrm{C}$, DPS is higher than at the other temperature treatments (Fig. 2). Even though there is no strong statistical significance in salinity $\left(F_{1}=4.478, p=0.0449\right)$,
Fig. 1 Maximum quantum yield $\left(F_{\mathrm{v}} / F_{\mathrm{m}}\right)$ of Laminaria solidungula during the multiplestressor experiment with four temperatures $(0,5,10$, $\left.15^{\circ} \mathrm{C}\right)$ and two salinities $\left(S_{\mathrm{A}}\right.$ $25,35)$. The gray background represents the temperature acclimation phase. The white background represents the temperature $\times$ salinity treatment phase. Values are means \pm SD $(n=4)$. Significant differences in final data points are marked with different letters (two-way ANOVA with post hoc Tukey's test; $p<0.05$ )

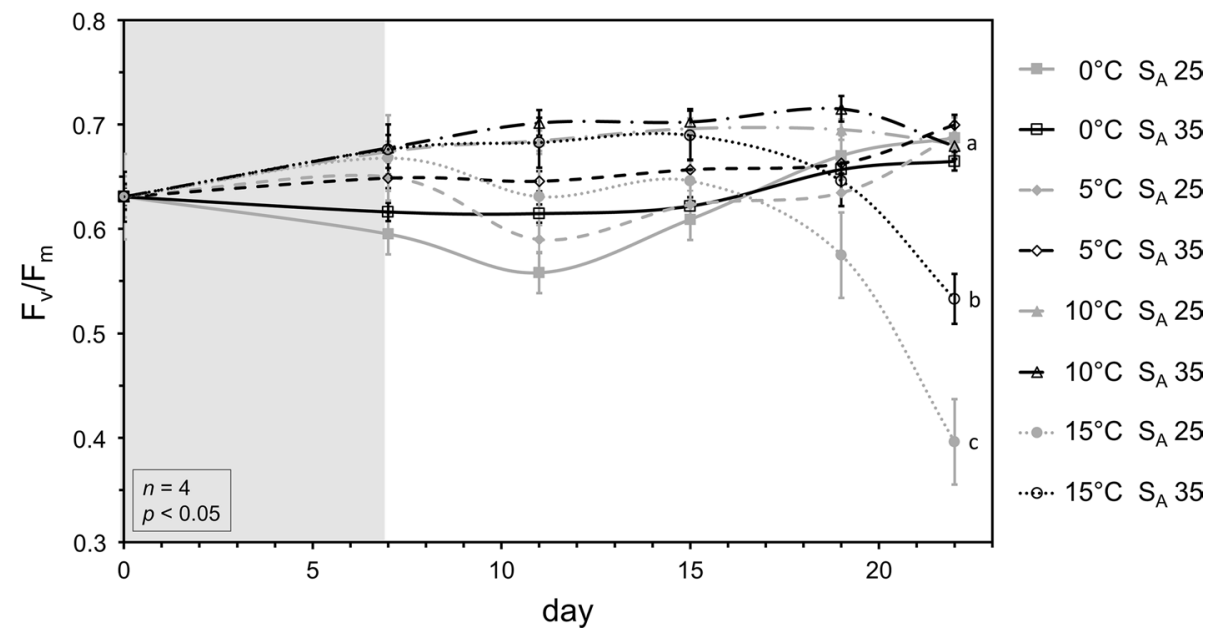

Table 1 Difference in pigment concentration $\left[\mu \mathrm{g} \mathrm{g}^{-1}\right.$ dry weight (DW)] and phlorotannin concentration ( $\mathrm{mg} \mathrm{g}^{-1} \mathrm{DW}$ ) in Laminaria solidungula after a 2-week exposure in a multiple-stressor experiment with four temperatures $\left(0,5,10,15{ }^{\circ} \mathrm{C}\right)$ and two salinities $\left(S_{\mathrm{A}}\right.$
25, 35): chlorophyll $a$ (Chl $a$ ), chlorophyll c2 (Chl c2), fucoxanthin (Fuc), $\beta$-carotene ( $\beta$-Car), and the pool of the xanthophyll cycle pigments (VAZ: violaxanthin, antheraxanthin, zeaxanthin) and soluble phlorotannins

\begin{tabular}{|c|c|c|c|c|c|c|c|}
\hline Temp. $\left({ }^{\circ} \mathrm{C}\right)$ & $S_{\mathrm{A}}$ & $\begin{array}{l}\text { Chl } a \\
\left(\mu \mathrm{g} \mathrm{g}^{-1} \mathrm{DW}\right)^{\mathrm{a}}\end{array}$ & $\begin{array}{l}\text { Chl c2 } \\
\left(\mu \mathrm{g} \mathrm{g}^{-1} \mathrm{DW}\right)\end{array}$ & $\begin{array}{l}\text { Fuc } \\
\left(\mu \mathrm{g} \mathrm{g}^{-1} \mathrm{DW}\right)^{\mathrm{a}}\end{array}$ & $\begin{array}{l}\beta-C a r \\
\left(\mu g^{-1} D W\right)^{a}\end{array}$ & $\begin{array}{l}\text { VAZ } \\
\left(\mu \mathrm{g} \mathrm{g}^{-1} \mathrm{DW}\right)^{\mathrm{b}}\end{array}$ & $\begin{array}{l}\text { Phlorotannins } \\
\left(\mathrm{mg} \mathrm{g}^{-1} \mathrm{DW}\right)\end{array}$ \\
\hline \multirow[t]{2}{*}{0} & 25 & $602.14( \pm 94.29) \mathrm{a}$ & $182.84( \pm 11.90) a$ & $416.49( \pm 58.40) a$ & $77.37( \pm 6.04) \mathrm{a}$ & $84.99( \pm 52.78) \mathrm{c}$ & $1.29( \pm 0.16) \mathrm{ab}$ \\
\hline & 35 & $\begin{array}{l}509.75( \pm 181.89) \\
\text { abc }\end{array}$ & $156.37( \pm 42.05) \mathrm{a}$ & $352.31( \pm 111.02) \mathrm{a}$ & $63.54( \pm 13.38) a b$ & $88.14( \pm 6.07) b c$ & $1.42( \pm 0.12) \mathrm{abc}$ \\
\hline \multirow[t]{2}{*}{5} & 25 & $551.13( \pm 67.98) \mathrm{ab}$ & $171.86( \pm 13.64) a$ & $395.16( \pm 43.84) a$ & $75.35( \pm 5.13) a b$ & $75.50( \pm 19.56) \mathrm{abc}$ & $1.60( \pm 0.19) \mathrm{c}$ \\
\hline & 35 & $\begin{array}{l}512.39( \pm 77.36) \\
\text { abc }\end{array}$ & $165.26( \pm 10.96) \mathrm{a}$ & $370.47( \pm 47.86) \mathrm{a}$ & $71.17( \pm 2.42) \mathrm{ab}$ & $55.38( \pm 10.24) \mathrm{ab}$ & $1.43( \pm 0.15) \mathrm{cb}$ \\
\hline \multirow[t]{2}{*}{10} & 25 & $406.49( \pm 55.12) \mathrm{bc}$ & $128.88( \pm 21.67) a$ & $303.61( \pm 41.94) a$ & $59.27( \pm 11.40) a b$ & $45.36( \pm 17.94) \mathrm{a}$ & $1.42( \pm 0.13) \mathrm{ab}$ \\
\hline & 35 & $878.25( \pm 206.58) \mathrm{c}$ & $202.54( \pm 22.19) a$ & $573.65( \pm 107.87) \mathrm{a}$ & $77.99( \pm 7.86) a b$ & $85.86( \pm 26.29) \mathrm{c}$ & $1.24( \pm 0.12) \mathrm{a}$ \\
\hline \multirow[t]{2}{*}{15} & 25 & $761.35( \pm 45.55) b c$ & $171.24( \pm 9.59) \mathrm{a}$ & $517.91( \pm 29.52) \mathrm{a}$ & $75.20( \pm 4.23) \mathrm{ab}$ & $101.24( \pm 6.41) \mathrm{c}$ & $1.35( \pm 0.19) \mathrm{ab}$ \\
\hline & 35 & $\begin{array}{l}609.79( \pm 55.48) \\
\text { abc }\end{array}$ & $170.94( \pm 4.15) \mathrm{a}$ & $418.52( \pm 36.11) \mathrm{a}$ & $78.03( \pm 2.03) \mathrm{b}$ & $92.34( \pm 10.72) \mathrm{c}$ & $1.20( \pm 0.18) \mathrm{a}$ \\
\hline
\end{tabular}

Significant differences are marked with different letters $(n=4$; generalized linear model [GLM]; $p<0.05$; further stastistical details in Supplementary Table 1)

${ }^{a}$ Reciprocal

${ }^{\mathrm{b}} \log _{10}$ transformation 


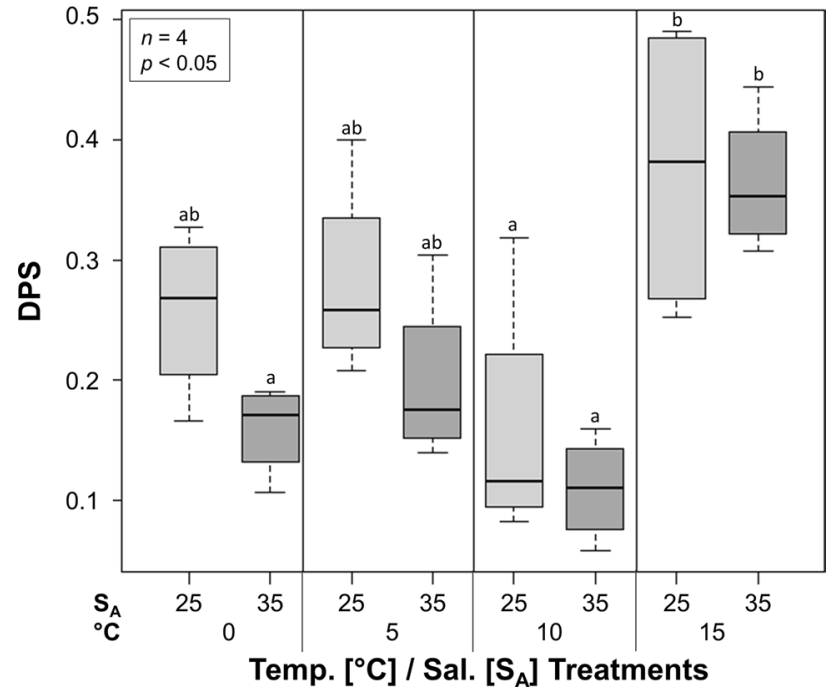

Fig. 2 Deepoxydation state of the xanthophyll cycle (DPS) of Laminaria solidungula after a 2-week exposure in a multiple-stressor experiment with four temperatures $\left(0,5,10,15^{\circ} \mathrm{C}\right)$ and two salinities $\left(S_{\mathrm{A}} 25,35\right)$. Significant differences in final data points are marked with different letters ( $n=4$; two-way ANOVA with post hoc Tukey's test; $p<0.05$ )

a clear trend to lower DPS values at $S_{\mathrm{A}} 35$ can be projected. Hence, DPS is increasing with increasing physical stressors.

\section{Mannitol}

Temperature and salinity stress affected the mannitol concentration significantly (Fig. 3), both individually (temperature: $F_{3}=7.038, p=0.0015$; salinity: $F_{1}=79.520$, $p<0.0001)$ and interactively $\left(F_{3}=79.520, p=0.0027\right)$. Regarding the control salinity treatment $\left(S_{\mathrm{A}} 35\right)$, only the $15{ }^{\circ} \mathrm{C}$ treatment showed a significant decrease in mannitol from about $1600\left(0-10{ }^{\circ} \mathrm{C}\right)$ to $1,323 \pm 78 \mu \mathrm{mol} \mathrm{mg}{ }^{-1}$ $\mathrm{DW}\left(n=4 ; 0{ }^{\circ} \mathrm{C}: p=0.0111 ; 5{ }^{\circ} \mathrm{C}: p=0.0393 ; 10{ }^{\circ} \mathrm{C}\right.$ : $p=0.0266)$. The samples incubated at low salinity $\left(S_{\mathrm{A}} 25\right)$ generally contained less mannitol than the control salinity samples across all temperatures, with significant differences at $0{ }^{\circ} \mathrm{C}(p<0.0001)$ and $5{ }^{\circ} \mathrm{C}(p=0.0002)$. Temperature and salinity stress showed an interactive and additive effect on mannitol, since the concentration in samples at $S_{\mathrm{A}} 25$ increased from 0 to $10{ }^{\circ} \mathrm{C}$. Apparently, temperatures beyond the optimum range limited the alga's ability to compensate salinity differences, resulting in a decrease of mannitol at $S_{\mathrm{A}}$ 35 as well as $S_{\mathrm{A}} 25$.

\section{Carbon, nitrogen and C:N ratio}

The carbon:nitrogen (C:N) ratio (Fig. 4a) was significantly affected by temperature $\left(F_{3}=280.872, p<0.0001\right)$, salinity $\left(F_{1}=121.773, p<0.0001\right)$, and by the interaction of

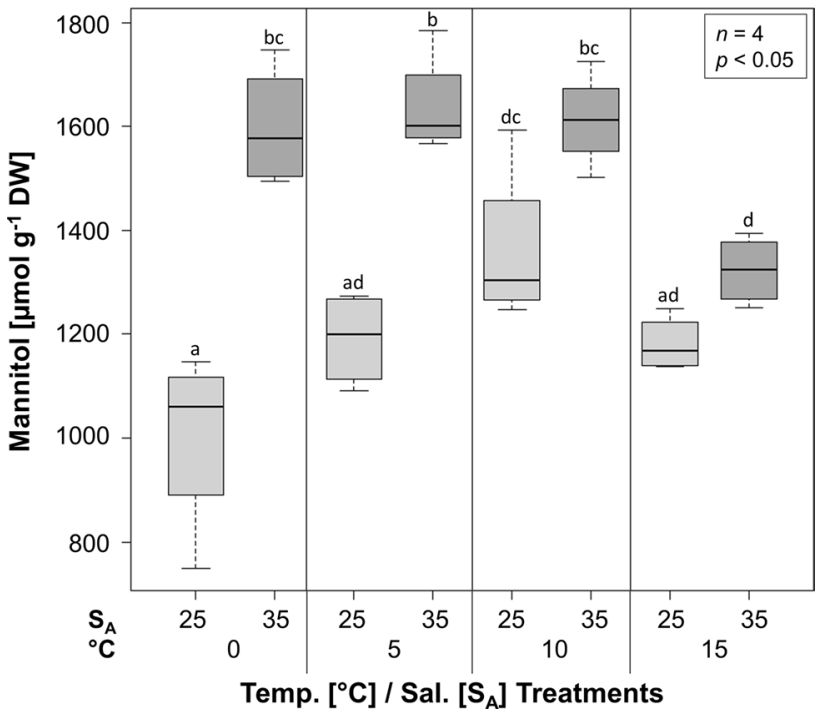

Fig. 3 Mannitol concentration $\left[\mu \mathrm{mol} \mathrm{g} \mathrm{g}^{-1}\right.$ dry weight (DW)] in Laminaria solidungula after a 2-week exposure in a multiple-stressor experiment with four temperatures $\left(0,5,10,15^{\circ} \mathrm{C}\right)$ and two salinities $\left(S_{\mathrm{A}} 25,35\right)$. Significant differences are marked with different letters $(n=4$; two-way ANOVA with post hoc Tukey's test; $p<0.05)$

both physical factors $\left(F_{3}=4.025, p=0.0188\right)$. The results indicated an antagonistic effect of increased temperature and low salinity. With higher temperatures, the $\mathrm{C}: \mathrm{N}$ ratio was significantly higher. The $\mathrm{C}: \mathrm{N}$ ratio increased above 20 at 10 and $15^{\circ} \mathrm{C}$ at both salinities, while it was below 20 at 5 and $10^{\circ} \mathrm{C}$. Additionally, at each temperature, the $\mathrm{C}: \mathrm{N}$ ratio at $S_{\mathrm{A}} 25$ was significantly lower than at the control of $S_{\mathrm{A}} 35$.

For further exploration, the total $\mathrm{C}$ and total $\mathrm{N}$ contents were analyzed. Temperature increase $\left(F_{3}=22.494\right.$, $p<0.0001)$ and salinity decrease $\left(F_{1}=6.564, p=0.0171\right)$ had each a significant and an interactive antagonistic $\left(F_{3}=4.341, p=0.0140\right)$ impact on the total $\mathrm{N}$ content (Fig. 4c). On the one hand, the total $\mathrm{N}$ content decreased at higher temperatures $\left(10,15^{\circ} \mathrm{C}\right)$ at both salinities. On the other hand, the $\mathrm{N}$ concentration increased at $S_{\mathrm{A}} 25$ at each temperature, compared to the control $S_{\mathrm{A}} 35$. The total C content (Fig. 4b) barley changed (temperature: $F_{3}=178.729$, $p<0.0001$; salinity: $F_{1}=78.823, p<0.0001$ ), with slight changes in the range of $331 \pm 14$ and $378 \pm 2 \mathrm{mg} \mathrm{g}^{-1} \mathrm{DW}$ $(n=4)$. Hence, the increasing C:N ratio was mainly driven by $\mathrm{N}$ variations. However, the $\mathrm{C}$ content increased at $10{ }^{\circ} \mathrm{C} /$ $S_{\mathrm{A}} 35,15{ }^{\circ} \mathrm{C} / S_{\mathrm{A}} 35$ and $15{ }^{\circ} \mathrm{C} / S_{\mathrm{A}} 25$, which balanced out the variation in $\mathrm{C}: \mathrm{N}$ ratio in these treatments.

\section{Discussion}

The interactive effects of different temperatures and salinities revealed strong physiological and biochemical responses in Laminaria solidungula towards a changing environment. 
Fig. 4 Carbon $(\mathrm{C})$ and nitrogen $(\mathrm{N})$ content in Laminaria solidungula after a 2-week exposure in a multiple-stressor experiment with four temperatures $\left(0,5,10,15{ }^{\circ} \mathrm{C}\right)$ and two salinities $\left(S_{\mathrm{A}} 25,35\right)$. Significant differences are marked with different letters $(n=4$; twoway ANOVA with post hoc Tukey's test; $p<0.05)$. a C:N ratio. The dashed line represents the mean $\mathrm{C}: \mathrm{N}$ ratio of temperate and tropical seaweeds (Atkinson and Smith 1983). b Total carbon (C) concentration $\left[\mathrm{mg} \mathrm{g}^{-1}\right.$ dry weight (DW)]. c: Total nitrogen (N) concentration $\left(\mathrm{mg} \mathrm{g}^{-1} \mathrm{DW}\right)$

It has been shown in macroalgae before that under multiplestressor conditions, the effects on the physiological performance and biochemical constituents often either interact in an additive or antagonistic manner (Fredersdorf et al. 2009; Gordillo et al. 2016; Springer et al. 2017). As an Arctic endemic species, $L$. solidungula is adapted to low temperatures (tom Dieck (Bartsch) 1992) and it is characterized as a stenohaline species (Karsten 2007). The present study indeed demonstrated the vulnerability of this species to changes in environmental parameters by exposing it to abiotic conditions beyond the ambient range.

As had been observed before, photosynthetic optimum quantum yield $\left(F_{\mathrm{v}} / F_{\mathrm{m}}\right)$ was inhibited by lower salinities and temperature stress (Kirst 1989; Fredersdorf 2009; Nitschke et al. 2014; Ji et al. 2016). Independently of salinity, $15{ }^{\circ} \mathrm{C}$ has a major impact on $F_{\mathrm{v}} / F_{\mathrm{m}}$, resulting in a significant diminishment of the photosynthetic capacity. Temperature-induced stress in the thalli of $L$. solidungula was also reported by Parages et al. (2013). Mitogen-activated protein (MAP) kinase-like proteins, which are involved in stress responses, were rapidly activated at $7{ }^{\circ} \mathrm{C}$. Karsten (2007) hypothesized a temperature-limited physiological capacity of cold-temperate and Arctic species to acclimate to external salinity changes. This hypothesis could be confirmed in this study. The combination of low salinity and for the Arctic extreme temperatures of $15{ }^{\circ} \mathrm{C}$ inhibited the photosynthetic activity and diminished the mannitol content of L. solidungula significantly. Karsten (2007) showed that the photosynthetic performance can be maintained for a short period of stress, but is affected after continued stress exposure, by comparing quantum yields in several Arctic macroalgae after two and five days of treatment. We were able to confirm this effect, however, the significant decrease of $F_{\mathrm{v}} / F_{\mathrm{m}}$ only occurred after 2 weeks. This shows that $L$. solidungula can compensate stress for a short period but is susceptible if environmental stressors are applied for a longer period. Mannitol is a carbohydrate of low molecular weight and known to play a significant role in the water balance of algal cells (Kirst 1989). Acting as an osmolyte and compatible solute, it preserves the functions of the cells during osmotic stress (Kirst 1989; Eggert et al. 2007). In our experiment, less mannitol was apparently stored in the cells of $L$. solidungula to prevent water flow into the cells under hypoosmotic stress $\left(S_{\mathrm{A}} 25\right)$, while at $S_{\mathrm{A}} 35$ the mannitol
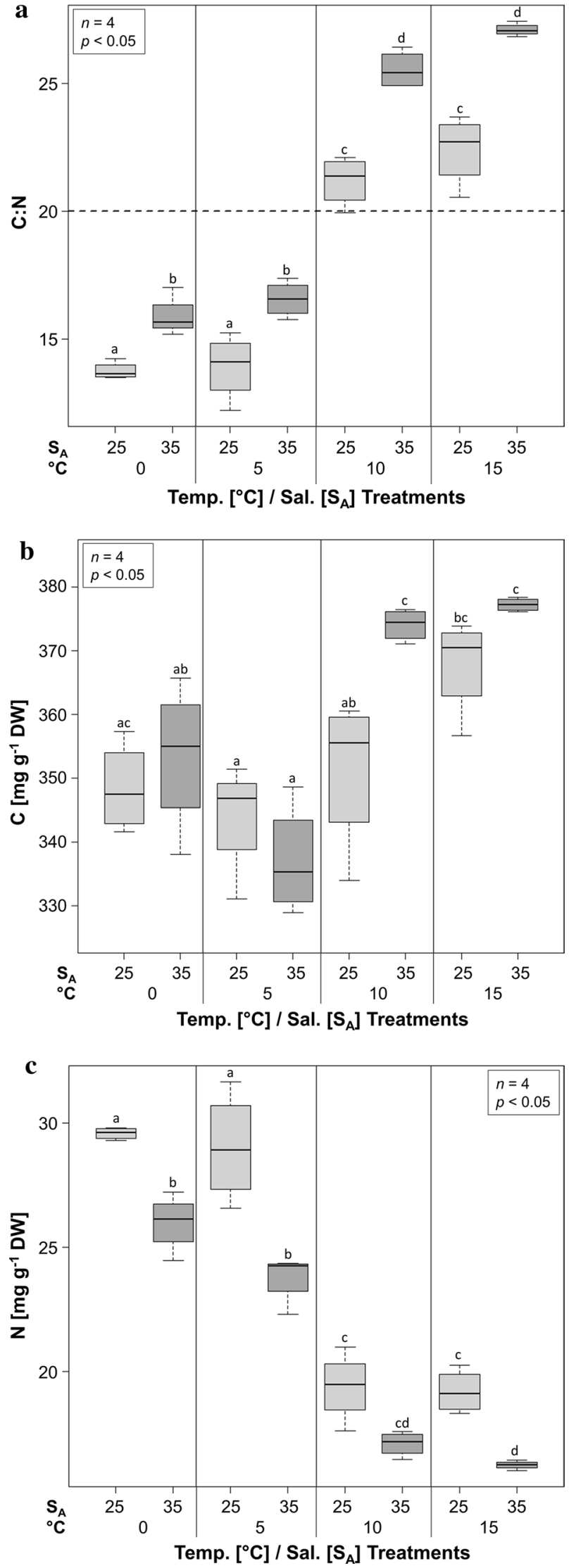
content remained almost unchanged. Nevertheless, in this study an impact of temperature was also observed. Since mannitol is the main photosynthetic product of brown algae, it was affected by temperature ( $\mathrm{Ji}$ et al. 2016). The optimum growth temperature of $L$. solidungula was determined to be $5-10{ }^{\circ} \mathrm{C}$ (tom Dieck (Bartsch) 1992). It is generally known that with increasing temperature the enzymatic processes accelerate, while temperature stress above a certain threshold leads to inhibition of metabolic processes (Graiff et al. 2015b). Accordingly, the mannitol concentration in $L$. solidungula increased at $S_{\mathrm{A}} 25$ between 0 and $10^{\circ} \mathrm{C}$ and decreased at $15{ }^{\circ} \mathrm{C}$, likely being in the range of inhibited metabolic processes.

In contrast to studies by Davison et al. (1991) and CelisPlá et al. (2014), a dependence of the absolute pigment content on growth temperatures, photosynthetic efficiency or other environmental stressors could not be confirmed in this study (Table 1). Furthermore, contrary to Mannino et al. (2016) and Springer et al. (2017), there was no significant increase or decrease of antioxidants due to stress treatment observed on any level (Table 1).

Even though no changes in the pool-size of xanthophylls (VAZ) were detected, the deepoxydation state (DPS) was significantly affected by temperature and increased at $15^{\circ} \mathrm{C}$. Furthermore, higher DPS in the low salinity treatments was detected. Changes in the xanthophyll cycle and hence the DPS are an important stress response in seaweeds, mainly as protection against photo-oxidative stress (Müller et al. 2001; Goss and Jakob 2010). Li et al. (2019) and Olischläger et al. (2017) detected an increase of DPS at the suboptimal temperatures in Saccharina latissima from the Arctic and Helgoland. These two studies and the result of our study support the hypothesis, that stress, such as suboptimal temperatures or hyposalinity, is also compensated by an increasing DPS in seaweeds.

A clear temperature-driven increase of the $\mathrm{C}: \mathrm{N}$ ratio could not be determined in this study, even though it already has been reported in L. solidungula and other polar macroalgae (Dunton and Schell 1986; Gordillo et al. 2006; Graiff et al. 2015a). Nonetheless, at higher temperatures (10 and $15^{\circ} \mathrm{C}$ ), the $\mathrm{C}: \mathrm{N}$ ratio was significantly increased than at lower temperatures $\left(0\right.$ and $\left.5{ }^{\circ} \mathrm{C}\right)$, showing a general negative impact of high temperatures in L. solidungula. Additionally, in contrast to Graiff et al. (2015a) a decrease in C:N ratio, as has been shown in $F$. vesiculosus at very high temperatures, could not be confirmed. Instead, we observed a direct correlation of temperature to the increase in $\mathrm{C}: \mathrm{N}$ ratio. Atkinson and Smith (1983) showed that benthic marine algae from temperate and tropical regions had a mean $\mathrm{C}: \mathrm{N}$ ratio of 20 , while 10 was considered to be very low and indicative for sufficient $\mathrm{N}$ supply. In L. solidungula, the $\mathrm{C}: \mathrm{N}$ ratio increased above 20 at 10 and $15{ }^{\circ} \mathrm{C}$, indicating $\mathrm{N}$ limitation (Atkinson and Smith 1983; Peters et al. 2005). With the analyses of total $\mathrm{C}$ and total $\mathrm{N}$, the strong increase in the $\mathrm{C}: \mathrm{N}$ ratio could be explained by a strong decrease of total $\mathrm{N}$ content in the samples. The total $\mathrm{C}$ content constitutes all carbohydrates, including all polysaccharides and is affected by the tissue structure (Peters et al. 2005). With changing photosynthetic activity or growth, $\mathrm{C}$ assimilation and $\mathrm{C}$ utilization can be affected (Gómez and Wiencke 1998; Gevaert et al. 2001). Nevertheless, a clear impact of temperature or salinity on the total $\mathrm{C}$ content could not be detected. Contrarily, the amount of total $\mathrm{N}$ decreased significantly with increasing temperatures, which means less $\mathrm{N}$ is taken up from the medium and stored as organic molecules and amino acids in the tissue (Gevaert et al. 2001). To exclude any effect of the experimental design on the reduced $\mathrm{N}$ uptake, sufficient $\mathrm{N}$ supply in the medium was ensured. In fact, the $\mathrm{N}$ accumulation in L. solidungula must therefore be intrinsically inhibited by temperature increase and at control salinity. Decreases in $\mathrm{N}$ concentrations might be explained, for example, by decreased nitrate reductase activity, protein synthesis and limited $\mathrm{N}$ storage as has been shown by Reay et al. (1999) and Gordillo et al. (2006). An increasing $\mathrm{N}$ uptake at lower salinities was previously detected in Fucus serratus and explained by an increased $\mathrm{N}$ metabolism at lower salinities (Gordillo et al. 2002). Mandal et al. (2015) showed a dependence of temperature and salinity on $\mathrm{N}$ uptake in the red alga Kappaphycus alvarezii. In land plants, a reduced $\mathrm{N}$ uptake was detected in saline soils, due to enhanced chloride concentrations in the soil (Mansour 2000). This fact can also be assigned to seaweed and seawater. Hence, an increasing $\mathrm{N}$ metabolism could have led to the higher $\mathrm{N}$ concentrations at the low salinity treatments in L. solidungula.

In conclusion, salinity and temperature had an additive and antagonistic impact on the Arctic seaweed L. solidungula, depending on the analyzed response variable. Concerning photosynthetic processes, L. solidungula seems to be well adapted to its Arctic habitat with natural temperature and salinity variations, but being restricted by the extreme temperature of $15^{\circ} \mathrm{C}$. L. solidungula tolerated $0-10{ }^{\circ} \mathrm{C}$ and could compensate the decreasing salinities at these temperatures, while at $15{ }^{\circ} \mathrm{C}$ the osmotic stress at control salinity could not be compensated anymore. Furthermore, this study confirms that abiotic stressors can be compensated for a short period of time (e.g., Karsten 2007; Simonson et al. 2015a). Even though the absolute pigment content was not affected by the two stressors, the DPS increased to compensate rising physiological stress. Regarding mannitol, temperature increase and salinity decrease affected the concentration additively. Suboptimal temperatures resulted in lower mannitol concentrations at low salinity, while the control salinity $S_{\mathrm{A}} 35$ resulted in higher concentrations independent from temperature. Temperatures exceeding the optimum range limited the alga's ability to compensate salinity differences. Contrary to mannitol, temperature and 
salinity had an antagonistic impact on total $\mathrm{N}$ and hence the $\mathrm{C}: \mathrm{N}$ ratio, as increasing temperature resulted in decreasing $\mathrm{N}$ content. Nonetheless, $S_{\mathrm{A}} 25$ could compensate for temperature interferences.

Our results demonstrate the importance of research on physiological and biochemical responses to interactions of two or more environmental stress factors, regarding consequences of climate change. In accordance to the study of Müller et al. (2009) on polar seaweeds under ocean warming, we can confirm that also the combination of several emerging environmental stressors may result in a retreat or even extinction of some L. solidungula populations and a shifting into higher Arctic Regions.

Acknowledgements Open Access funding provided by Projekt DEAL. The authors are grateful to Inka Bartsch, Andreas Wagner and Claudia Daniel (Alfred Wegener Institute) for cultivating the sporophytes and for providing the facilities to conduct the experiment. This study is part the German Research Foundation for funding within the ERA-Net Cofund BiodivERsA 3 program MARFOR (ANR-16-EBI3-0005-01).

\section{Compliance with ethical standards}

Conflict of interest All authors declare that they are free of competing interests.

Open Access This article is licensed under a Creative Commons Attribution 4.0 International License, which permits use, sharing, adaptation, distribution and reproduction in any medium or format, as long as you give appropriate credit to the original author(s) and the source, provide a link to the Creative Commons licence, and indicate if changes were made. The images or other third party material in this article are included in the article's Creative Commons licence, unless indicated otherwise in a credit line to the material. If material is not included in the article's Creative Commons licence and your intended use is not permitted by statutory regulation or exceeds the permitted use, you will need to obtain permission directly from the copyright holder. To view a copy of this licence, visit http://creativecommons.org/licenses/by/4.0/.

\section{References}

Andersen G, Pedersen M, Nielsen S (2013) Temperature acclimation and heat tolerance of photosynthesis in Norwegian Saccharina latissima (Laminariales, Phaeophyceae). J Phycol 700:689-700. https://doi.org/10.1111/j.1529-8817.2013.12077

Atkinson MJ, Smith SV (1983) C:N:P ratios of benthic marine plants. Limnol Oceanogr 28:568-574

Bartsch I, Paar M, Fredriksen S, Schwanitz M, Daniel C, Hop H, Wiencke C (2016) Changes in kelp forest biomass and depth distribution in Kongsfjorden, Svalbard, between 1996-1998 and 20122014 reflect Arctic warming. Polar Biol 39:2021-2036. https:// doi.org/10.1007/s00300-015-1870-1

Bischof K (2002) Effects of solar UV-B radiation on canopy structure of Ulva communities from southern Spain. J Exp Bot 53:24112421. https://doi.org/10.1093/jxb/erf091

Bischof K, Hanelt D, Aguilera J, Karsten U, Vögele B, Sawall T, Wiencke C (2002) Seasonal variation in ecophysiological patterns in macroalgae from an Arctic fjord. I. Sensitivity of photosynthesis to ultraviolet radiation. Mar Biol 140:1097-1106. https://doi. org/10.1007/s00227-002-0795-8

Bluhm BA, Gradinger R (2008) Regional variability in food availability for Arctic marine mammals. Ecol Appl 18:77-96. https://doi. org/10.1890/06-0562.1

Celis-Plá PSM, Martínez B, Quintano E, García-Sánchez M, Pedersen A, Navarro NP, Copertino MS, Mangaiyarkarasi N, Mariath R, Figueroa FL, Korbee N (2014) Short-term ecophysiological and biochemical responses of Cystoseira tamariscifolia and Ellisolandia elongata to environmental changes. Aquat Biol 22:227-243. https://doi.org/10.3354/ab00573

Colombo-Pallotta MF, García-Mendoza E, Ladah LB (2006) Photosynthetic performance, light absorption, and pigment composition of Macrocystis pyrifera (Laminariales, Phaeophyceae) blade from different depths. J Phycol 42:1225-1234. https:// doi.org/10.1111/j.1529-8817.2006.00287.x

Cruces E, Huovinen P, Gómez I (2012) Phlorotannin and antioxidant responses upon short-term exposure to UV radiation and elevated temperature in three south Pacific kelps. Photochem Photobiol 88:58-66. https://doi.org/10.111 1/j.1751-1097.2011.01013.x

Dashboard AWI (2019) Wagner C: Water temperatures-NyÅlesund/ Svalbard-N78 $55.200 / \mathrm{E} 11^{\circ} 54.00$. Alfred-Wegener-Institute. https://dashboard.awi.de/?dashboard=2847. Accessed 11 Sept 2019

Davison IR, Greene RM, Podolak EJ (1991) Temperature acclimation of respiration and photosynthesis in the brown alga Laminaria saccharina. Mar Biol 110:449-454. https://doi.org/10.1007/ BF01344363

Diehl N, Michalik D, Zuccarello GC, Karsten U (2019) Stress metabolite pattern in the eulittoral red alga Pyropia plicata (Bangiales) in New Zealand-mycosporine-like amino acids and heterosides. J Exp Mar Bio Ecol 510:23-30. https://doi.org/10.1016/j.jembe .2018 .10 .002

Dunton KH, Schell DM (1986) Seasonal carbon budget and growth of Laminaria solidungula in the Alaskan High Arctic. Mar Ecol 31:57-66. https://doi.org/10.3354/meps031057

Eggert A, Nitschke U, West JA, Michaelik D, Karsten U (2007) Acclimation of the intertidal red alga Bangiopsis subsimplex (Stylonematophyceae) to salinity changes. J Exp Mar Biol Ecol 343:176186. https://doi.org/10.1016/j.jembe.2006.11.015

Fernandes F, Barbosa M, Oliveira AP, Azevedo IC, Sousa-Pinto I, Valentão P, Andrade PB (2016) The pigments of kelps (Ochrophyta) as part of the flexible response to highly variable marine environments. J Appl Phycol 28:3689-3696. https://doi. org/10.1007/s10811-016-0883-7

Filbee-Dexter K, Wernberg T, Fredriksen S, Norderhaug KM, Pedersen MF (2019) Arctic kelp forests: Diversity, resilience and future. Glob Planet Change 172:1-14. https://doi.org/10.1016/j.glopl acha.2018.09.005

Fredersdorf J (2009) Interactive abiotic stress effects on Arctic marine macroalgae-physiological responses of adult sporophytes. Dissertation, University of Bremen

Fredersdorf J, Müller R, Becker S, Wiencke C, Bischof K (2009) Interactive effects of radiation, temperature and salinity on different life history stages of the Arctic kelp Alaria esculenta (Phaeophyceae). Oecologia 160:483-492. https://doi.org/10.1007/s0044 2-009-1326-9

Gevaert F, Davoult D, Creach A, Kling R, Janquin MA, Seuront L, Lemoine Y (2001) Carbon and nitrogen content of Laminaria saccharina in the eastern English Channel: biometrics and seasonal variations. J Mar Biol Assoc U K 81:727-734. https://doi. org/10.1017/s0025315401004532

Gómez I, Wiencke C (1998) Seasonal changes in C, N and major organic compounds and their significance to morpho-functional processes in the endemic Antarctic brown alga Ascoseira 
mirabilis. Polar Biol 19:115-124. https://doi.org/10.1007/s0030 00050222

Gordillo FJL, Dring MJ, Savidge G (2002) Nitrate and phosphate uptake characteristics of three species of brown algae cultured at low salinity. Mar Ecol Prog Ser 234:111-118. https://doi. org/10.3354/meps234111

Gordillo FJL, Aguilera J, Jiménez C (2006) The response of nutrient assimilation and biochemical composition of Arctic seaweeds to a nutrient input in summer. J Exp Bot 57:2661-2671. https://doi. org/10.1093/jxb/er1029

Gordillo FJL, Carmona R, Viñegla B, Wiencke C, Jiménez C (2016) Effects of simultaneous increase in temperature and ocean acidification on biochemical composition and photosynthetic performance of common macroalgae from Kongsfjorden (Svalbard). Polar Biol 39:1993-2007. https://doi.org/10.1007/s0030 0-016-1897-y

Goss R, Jakob T (2010) Regulation and function of xanthophyll cycledependent photoprotection in algae. Photosynth Res 106:103-122. https://doi.org/10.1007/s11120-010-9536-x

Graiff A, Bartsch I, Ruth W, Wahl M, Karsten U (2015a) Season exerts differential effects of ocean acidification and warming on growth and carbon metabolism of the seaweed Fucus vesiculosus in the western Baltic Sea. Front Mar Sci 2:1-18. https://doi.org/10.3389/ fmars.2015.00112

Graiff A, Liesner D, Karsten U, Bartsch I (2015b) Temperature tolerance of western Baltic Sea Fucus vesiculosus - growth, photosynthesis and survival. J Exp Mar Biol Ecol 471:8-16. https://doi. org/10.1016/j.jembe.2015.05.009

Hanelt D, Tüg H, Bischof K, Groß C, Lippert H, Sawall T, Wiencke C (2001) Light regime in an Arctic fjord: a study related to stratospheric ozone depletion as a basis for determination of UV effects on algal growth. Mar Biol 138:649-658

Heinrich S, Valentin K, Frickenhaus S, Wiencke C (2015) Temperature and light interactively modulate gene expression in Saccharina latissima (Phaeophyceae). J Phycol 51:93-108. https://doi. org/10.1111/jpy.12255

Hop H, Wiencke C, Vogele B, Kovaltchouk NA (2012) Species composition, zonation, and biomass of marine benthic macroalgae in Kongsfjorden, Svalbard. Bot Mar 55:399-414. https://doi. org/10.1515/bot-2012-0097

Iwamoto K, Shiraiwa Y (2005) Salt-regulated mannitol metabolism in algae. Mar Biotechnol 7:407-415. https://doi.org/10.1007/s1012 6-005-0029-4

Jacob A, Kirst GO, Wiencke C, Lehmann H (1991) Physiological responses of the Antarctic green alga Prasiola crispa ssp. antarctica to salinity stress. J Plant Physiol 139:57-62. https://doi. org/10.1016/S0176-1617(11)80165-3

Jacob A, Lehmann H, Kirst GO, Wiencke C (1992) Changes in the Uutrastructure of Prasiola crispa ssp. antarctica under salinity stress. Bot Acta 105:41-46. https://doi. org/10.1111/j.1438-8677.1992.tb00265.x

Ji Y, Xu Z, Zou D, Gao K (2016) Ecophysiological responses of marine macroalgae to climate change factors. J Appl Phycol 28:29532967. https://doi.org/10.1007/s10811-016-0840-5

Karsten U (2007) Salinity tolerance of Arctic kelps from Spitsbergen. Phycol Res 55:257-262

Karsten U, West JA (2000) Living in the intertidal zone-seasonal effects on heterosides and sun-screen compounds in the red alga Bangia atropurpurea (Bangiales). J Exp Mar Biol Ecol 254:221234. https://doi.org/10.1016/S0022-0981(00)00280-X

Karsten U, Thomas DN, Weykam G, Daniel C, Kirst GO (1991a) A simple and rapid method for extraction and separation of low molecular weight carbohydrates from macroalgae using highperformance liquid chromatography. Plant Physiol Biochem 29:373-378
Karsten U, Wiencke C, Kirst G (1991b) The effect of salinity changes upon the physiology of eulittoral green macroalgae from Antarctica and Southern Chile. J Exp Bot 42:1533-1539

Karsten U, Dummermuth A, Hoyer K, Wiencke C (2003) Interactive effects of ultraviolet radiation and salinity on the ecophysiology of two Arctic red algae from shallow waters. Polar Biol 26:249-258. https://doi.org/10.1007/s00300-002-0462-z

Kirst GO (1989) Salinity tolerance of eukaryotic marine algae. Annu Rev Plant Physiol Plant Mol Biol 40:21-53. https://doi. org/10.1146/annurev.pp.41.060190.000321

Koch K, Thiel M, Tellier F, Hagen W, Graeve M, Tala F, Laeseke P, Bischof K (2015) Species separation within the Lessonia nigrescens complex (Phaeophyceae, Laminariales) is mirrored by ecophysiological traits. Bot Mar 58:81-92. https://doi.org/10.1515/ bot-2014-0086

Li H, Monteiro C, Heinrich S, Bartsch I, Valentin K, Harms L, Glöckner G, Corre E, Bischof K (2019) Responses of the kelp Saccharina latissima (Phaeophyceae) to the warming Arctic: from physiology to transcriptomics. Physiol Plant. https://doi. org/10.1111/ppl.13009

Mandal SK, Ajay G, Monisha N, Malarvizhi J, Temkar G, Mantri VA (2015) Differential response of varying temperature and salinity regimes on nutrient uptake of drifting fragments of Kappaphycus alvarezii: implication on survival and growth. J Appl Phycol 27:1571-1581. https://doi.org/10.1007/s10811-014-0469-1

Mannino AM, Vaglica V, Cammarata M, Oddo E (2016) Effects of temperature on total phenolic compounds in Cystoseira amentacea (C. Agardh) Bory (Fucales, Phaeophyceae) from southern Mediterranean Sea. Plant Biosyst 150:152-160. https://doi. org/10.1080/11263504.2014.941033

Mansour MFF (2000) Nitrogen containing compounds and adaptation of plants to salinity stress. Biol Plantarium 43:491-500

Maturilli M, Herber A, König-Langlo G (2013) Climatology and time series of surface meteorology in Ny-Ålesund, Svalbard. Earth Syst Sci Data 5:155-163. https://doi.org/10.5194/ essd-5-155-2013

Meredith M, Sommerkorn M, Cassotta S, Derksen C, Ekaykin A, Hollowed A, Kofinas G, Mackintosh A, Melbourne-Thomas J, Muelbert MMC, Ottersen G, Pritchard H, Schuur EAG (2019) Polar regions. In: Pörtner HO, Roberts DC, Masson-Delmotte V, Zhai P, Tignor M, Poloczanska E, Mintenbeck K, Alegría A, Nicolai M, Okem A, Petzold J, Rama B, Weyer NM (eds) IPCC special report on the ocean and cryosphere in a changing climate (in press)

Müller P, Li X-P, Niyogi KK (2001) Non-photochemical quenching. A response to excess light energy. Plant Physiol 125:1558-1566

Müller R, Laepple T, Bartsch I, Wiencke C (2009) Impact of oceanic warming on the distribution of seaweeds in polar and coldtemperate waters. Bot Mar 52:617-638. https://doi.org/10.1515/ BOT.2009.080

Nitschke U, Karsten U, Eggert A (2014) Physiological performance of the red alga Stylonema alsidii (Stylonematophyceae) under varying salinities. J Exp Mar Bio Ecol 460:170-176. https://doi. org/10.1016/j.jembe.2014.07.007

Olischläger M, Bartsch I, Gutow L, Wiencke C (2012) Effects of ocean acidification on different life-cycle stages of the kelp Laminaria hyperborea (Phaeophyceae). Bot Mar 55:511-525. https://doi. org/10.1515/bot-2012-0163

Olischläger M, Iñiguez C, Koch K, Wiencke C, Gordillo FJL (2017) Increased $\mathrm{pCO}_{2}$ and temperature reveal ecotypic differences in growth and photosynthetic performance of temperate and Arctic populations of Saccharina latissima. Planta 245:119-136. https ://doi.org/10.1007/s00425-016-2594-3

Oliver ECJ, Donat MG, Burrows MT, Moore PJ, Smale DA, Alexander LV, Benthuysen JA, Feng M, Sen Gupta A, Hobday AJ, Holbrook NJ, Perkins-Kirkpatrick SE, Scannell HA, Straub SC, Wernberg $\mathrm{T}$ (2018) Longer and more frequent marine heatwaves over the 
past century. Nat Commun 9:1-12. https://doi.org/10.1038/s4146 7-018-03732-9

Parages ML, Heinrich S, Wiencke C, Jiménez C (2013) Rapid phosphorylation of MAP kinase-like proteins in two species of Arctic kelps in response to temperature and UV radiation stress. Environ Exp Bot 91:30-37. https://doi.org/10.1016/j.envexpbot.2013.02.005

Peters KJ, Amsler CD, Amsler MO, McClintock JB, Dunbar RB, Baker BJ (2005) A comparative analysis of the nutritional and elemental composition of macroalgae from the western Antarctic Peninsula. Phycologia 44:453-463. https://doi.org/10.2216/00318884(2005)44[453:ACAOTN]2.0.CO;2

Rautenberger R, Huovinen P, Gómez I (2015) Effects of increased seawater temperature on UV tolerance of Antarctic marine macroalgae. Mar Biol 162:1087-1097. https://doi.org/10.1007/s0022 7-015-2651-7

Reay DS, Nedwell DB, Priddle J, Cynan Ellis-Evans J (1999) Temperature dependence of inorganic nitrogen uptake: reduced affinity for nitrate at suboptimal temperatures in both algae and bacteria. Appl Environ Microbiol 65:2577-2584

Roleda MY (2016) Stress physiology and reproductive phenology of Arctic endemic kelp Laminaria solidungula. J Agardh Polar Biol 39:1967-1977. https://doi.org/10.1007/s00300-015-1813-x

Russell G (1987) Spatial and environmental components of evolutionary change: interactive effects of salinity and temperature on Fucus vesiculosus as an example. Helgoländer Meeresuntersuchungen 41:371-376. https://doi.org/10.1007/BF02366199

Simonson EJ, Metaxas A, Scheibling RE (2015a) Kelp in hot water: II. Effects of warming seawater temperature on kelp quality as a food source and settlement substrate. Mar Ecol Prog Ser 537:105-119. https://doi.org/10.3354/meps11421

Simonson EJ, Scheibling RE, Metaxas A (2015b) Kelp in hot water: I. Warming seawater temperature induces weakening and loss of kelp tissue. Mar Ecol Prog Ser 61:2180-2190. https://doi. org/10.1002/lno.10362

Smale DA, Wernberg T, Oliver ECJ, Thomsen M, Harvey BP, Straub SC, Burrows MT, Alexander LV, Benthuysen JA, Donat MG, Feng M, Hobday AJ, Holbrook NJ, Perkins-Kirkpatrick SE, Scannell HA, Sen Gupta A, Payne BL, Moore PJ (2019) Marine heatwaves threaten global biodiversity and the provision of ecosystem services. Nat Clim Chang 9:306-312. https://doi.org/10.1038/s4155 8-019-0412-1

Springer K, Cornelius L, Lütz-Meindl U, Wendt A, Bischof K (2017) Hyposaline conditions affect UV susceptibility in the Arctic kelp Alaria esculenta (Phaeophyceae). Phycologia 56:675-685. https ://doi.org/10.2216/16-122.1
Sundfjord A, Albretsen J, Kasajima Y, Kohler J, Nuth C, Skarðhamar J, Cottier F, Nilsen F, Asplin L, Gerland S, Torsvik T (2017) Effects of glacier runoff and wind on surface layer dynamics and Atlantic Water exchange in Kongsfjorden, Svalbard; a model study. Estuar Coast Shelf Sci 187:260-272. https://doi.org/10.1016/j. ecss.2017.01.015

Svendsen H, Beszczynska-Møller A, Hagen JO, Levauconnier B, Vigdis T, Gerland S, Børre Ørbæk J, Bischof K, Papucci C, Zajaczkowski M, Azzolini R, Bruland O, Wiencke C, Winther JG, Dallmann W (2002) The physical environment of Kongsfjorden-Krossfjorden, an Arctic fjord system in Svalbard. Polar Res 21:133-166

Thomas DN, Collins JC, Russell G (1988) Interactive effects of temperature and salinity upon net photosynthesis of Cladophora glomerata (L.) Kütz. and C. rupestris (L.) Kütz. Bot Mar 31:73-77. https://doi.org/10.1515/botm.1988.31.1.73

tom Dieck I (1989) Vergleichende Untersuchungen zur Ökophysiologie und Kreuzbarkeit innerhalb der digitaten Sektion der Gattung Laminaria Lamouroux (Phaeophyceae). Universität Hamburg, Hamburg

tom Dieck (Bartsch) I (1992) North Pacific and North Atlantic digitate Laminaria species (Phaeophyta): hybridization experiments and temperature responses. Phycologia 31:147-163. https://doi. org/10.2216/i0031-8884-31-2-147.1

Verardo DJ, Froelich PN, McIntyre A (1990) Determination of organic carbon and nitrogen in marine sediments using the Carlo Erba NA-1500 analyzer. Deep Res 37:157-165

Walczowski W, Piechura J, Goszczko I, Wieczorek P (2012) Changes in Atlantic water properties: an important factor in the European Arctic marine climate. ICES J Mar Sci 69:864-869

Wiencke C, Clayton MN, Gómez I, Iken K, Lüder UH, Amsler CD, Karsten U, Hanelt D, Bischof K, Dunton K (2007) Life strategy, ecophysiology and ecology of seaweeds in polar waters. Life Extrem Environ. https://doi.org/10.1007/978-1-4020-6285-8-13

Zacher K, Rautenberger R, Hanelt D, Wulff A, Wiencke C (2009) The abiotic environment of polar marine benthic algae. Bot Mar 52:483-490. https://doi.org/10.1515/BOT.2009.082

Publisher's Note Springer Nature remains neutral with regard to jurisdictional claims in published maps and institutional affiliations. 